\title{
The Role of Social Capital in Collective Action: The Case Study of Natural Resource Management
}

\author{
Abiy Serawitu \\ Dire Dawa Management and Kaizen Institute, Dire Dawa, Ethiopia
}

\begin{abstract}
The main objective of this study is to examine the role of social capital on collective action in natural resource management. Based on investigating a series of updated theoretical and empirical evidences on the role of social capital in collective action, mainly in natural resource management areas, the following common key findings are worth drawn:

Examined literatures generally indicated that natural resources need protection from destructive actions of people to achieve sustainable development. Thus far, communities have shown in the past and increasingly today that they can collaborate for long-term resource management. Social capital variables like heterogeneity index, bridging and linking social capital, civic engagement, cooperative norms, limited numbers of participants and formalized groups are found to be very significant and positively affecting collective action for community's achieving sustainable natural resource development. Particularly, indicated that the aforementioned variables are playing a fundamental role in reducing transaction cost of exchange like reducing cost of enforcing rules and information asymmetry; and improve local authority performance by pooling them in the networks.

This study is also aimed to review varies literatures to investigate whether there is positive relation between social capital and collective environmental action.Most study used model estimation of social capital variables in collective action revealed that the higher the social capital level, the more likely individual is willing to contribute in collective action to protect the natural resource. Results also found that individuals with higher degree of social capital are more likely to participate in collective actions because they can access more information, develop linkages and engage in decision making processes. Similarly, based on the findings, most literature also showed that in formalized groups, social capital is high, and people have the confidence to invest in collective activities in achieving their common natural resource goals.
\end{abstract}

Keywords: Social capital and collective action

DOI: $10.7176 /$ RHSS/11-19-02

Publication date:October $31^{\text {st }} 2021$

\section{Introduction}

Natural resource management is not only influenced by physical and economic capital but also social capital. According to Guillen et al (2015), Social capital is an indispensable aspect of community natural resource management implementation because communities surrounding the resource have limited physical and economic capital. Therefore, the communities need to preserve social capital to improve their economic wellbeing both directly and indirectly (Iswandono 2015). As for Coleman (1988) social capital refers to the individual and collective resources that can be mobilized through social relations and is applicable to the ground of community development endeavors.

Putnam (1993) defines social capital as trust, norms, and networks, which can improve the efficiency of society by facilitating coordinated actions. (Roslinda et al (2017argued that strong social capital should be given due consideration by the government to support community development programs. Social capital can facilitate the collective action of society and provide a strong influence on the process of improving social welfare. The value of trust in social capital is leading as the basis for communities to increase respect and mutual benefit. Trust is an necessary component of social capital formation in any country, while other aspects of cooperation and networking will not be well established if they are not based on mutual trust between community members (Cahyono 2014; Innah et al. 2013). Fisher (2013) pointed out that trust become an important medium that allows passive information to be transformed into valuable knowledge. The idea is supported by Guillen et al. (2015) who argued the importance of personal relationships and the catalyst role of social capital ties in natural resource management.

Many successful collective actions have been achieved by communities in natural resource management, but those still look some challenges when dealing with low social capital in society. Nooteboom (2006) revealed that the measurements of social capital are subjective, aspects of behavior, the limits of trust, and the distinction between reliability. Therefore, this term paper is aimed to study the role of social capital on collective action predominantly in natural resource management, particularly examining common attributes of social capital that can create varying capacities for different type's collective actions through the interplay of characteristics of trust, norms and networks in community resource management endeavours endeavors 


\subsection{Statement of the Problem}

Among the different capital assets owned by communities, social capital deserves particular policy attention because of its diverse nature and its potential influence on the development of formal and informal cooperation (Ostrom 1994) for achieving social and sustainable development.

More or less every country in the world has challenged by social capital problem to realize sustainable development. As government sector cannot do the task alone, the success of sustainable development must comprise contribution from all three stakeholders i.e. government, private sector and community. The potential of community to involve in solving social problems in collective action has been greater eventually and to be optimizing this potential, it is vital to understand well on the behavior of individual as an optimizing agent in the context of community collective action. Understanding and examining what common attributes of social capital, contribute in encouraging community to make collective action in all development endeavors are very useful for policy maker to consider in what way government can intervene and how can government make policy that can synergize between government and community action. As Cardenas and Ostrom (2004) mentioned that understanding the behavior of community and individual in communities making decisions to solve their common problem and how self- - governed solutions can emerge are both crucial to enhance policy analysis. In regard to the role of community, various studies have explored what drives individual participate in collective action and what makes it effective in solving community problem they are facing, however social capital factors s that are affecting the effectiveness of collective action in natural resource management endeavors are rare examined from different literatures; so this study is aimed at to address the aforementioned problem.

\subsection{Objective of the study}

1.2. The overall objective of this study is to examine the role of social capital on collective action in natural resource management

\section{Specific objectives}

- To examine the major top attributes of social capital that are affecting collective action in community natural resource management

- To examine the level of relations between social capital and collective action.

\section{Literature Review}

\subsection{Concept and definition of Social Capital}

The conceptualization of social capital has been chiefly crystallized into three broadly defined families of research. even though these share the concern with the effects of social relationships originally highlighted by Bourdieu, developed by Coleman and lengthily used by Putnam (Bourdieu 1985; Coleman 1988; Coleman 1990; Putnam, Leonardi, and Nanetti 1993), each of these families presents very different claims as to what social capital is and does, focusing in turn on socially accessed goods, social trust, and finally on networks and the norms bounded by them to realize their common goal collectively.

The first approach sees social capital as socially accessed resources, or goods obtained through networks, and are traceable to Pierre Bourdieu's definition of the concept. Bourdieu saw social capital as supplementary to physical and cultural capital: individuals use their personal networks to mobilize other types of goods (Bourdieu 1980; Bourdieu 1985). A comparable approach has been taken by sociologists working on social capital, especially those with a background in network theory, such as Nan Lin and Ronald Burt (Lin 1999; Burt 2000). This conceptualization is fundamentally different from the others to the level that it sees the resource in social capital as being the goods accessed through networks; while the others observe the social capital as resource in its own right. As Szreter and Woolcock wrote:"...the "mainstream" social capital literature, represented pragmatically by the work of Putnam, regards social capital as the "wires" while network theorists regard it as the "electricity" (Szreter and Woolcock 2004).

The additional two strands of social capital research take an interest in its capacity to facilitate cooperation and collective action, slightly than in its capacity to mobilize other resources. The social trust approach privileges the position of trust characters across entire societies taking a macro-level approach; the norms and networks approach takes a mainly meso perspective on the alike issue, looking for the sources of collective action in delimited groups and middle-order organizations both formal and informal.

Definitions of social capital that benefit the role of social trust as a source of cooperation and commonly beneficial collective action take a diversity of forms. Some see social capital as cultural features of societies in general that facilitate these actions, articulated through social trust and adherence to civic norms (Knack and Keefer 1997; Fukuyama 2001); others follow Robert Putnam's premature definitions of the concept and see social capital as the combination of networks with norms and values, usually expressed as individual answers to social trust and civic norms survey questions. now the relationship between trust and networks is hypothesized either one of two ways: in some cases participation in social networks are said to be the source of social trust and civic norms (Stolle 2003), even as other authors see social participation as a consequence of a society's level of trust and devotion to 
civic norms (Uslaner 2000).

The social trust approach has attracted widespread disapproval, whichever way the relationships between the elements of social capital are posited. Many authors have failed to find any clear relationship between individual cooperative acts, such as membership of voluntary associations, and social trust. Glaeser and his colleagues found little verification of trust embedded in networks being 'scaled-up' to social trust; in a comparative survey of association members, Stolle also found little substantiation of membership being strongly related to social trust, as contrasting to the usual variables of income, age, education and personal experience (Glaeser et al.1999; Stolle 2001; Stolle 2003). Studies using longitudinal data have also found no confirmation of social trust having a power on the joining of voluntary associations and only small effects of joining on trust (Claibourn and Martin 2000).

The last 'school' of social capital research focuses on the convergence of norms and networks within particular groups, and how these affect their capacity for collective action or cooperation. Such an interpretation is an important part of both James Coleman's and Robert Putnam's definitions of the thought, even though neither approach can be reduced to such a sparse concept. For Putnam, social norms and networks are '...an institutional mechanism with the power to ensure compliance with the collectively desirable behaviour' (Putnam 2000).

On top of were some of the questions left unanswered by the social trust perspective for which a norms and networks approach can give plausible answers. However, this study does not intend to discuss the relationship between social trust and social capital, rather to focus on examining common factors of social capital attributes affecting collective action in community development. Whilst leaving an open decision on the social trust 'school' of social capital, this very concise introduction to the concept does not intend to imply that a norms and networks approach to social capital is superior to the accessed resources school mentioned first in this review. Two points are necessary here: firstly, the role of norms and networks in providing access to resources, and in being resources themselves that can be triggered for collective action are not mutually exclusive dimensions, rather two sides of the same coin. Secondly, it must be recognized that access to resources is both a component and often an objective of collective action (a perspective that has, to my knowledge, been so far neglected by the network analysts discussed above, other than by treating groups as single individual units).

\subsection{The relation between Collective action and social capital}

Most studies have tried to relate collective action problem with social capital concept. Some keywords for this relation is reciprocity, trust, altruism, conditional cooperation, networks, institutions, social norms and rules. According to, Ahn and Ostrom (2002) have defined such relation by the second generation of collective action. Second generation of collective action is the development of previous theory on collective action which outlined by the Prisoner's Dilemma game, where in the first generation theories of collective action is an image of atomized, selfish, and fully rational individuals. The change has been made on the assumption on individual that it was proven in reality and empirical study, typically in field and laboratory experiment, there is a significant portion of individual that act non-selfish behavior (Ostrom \& Ahn, 2003). Likewise, Weible (2008) also tried to explain how cooperation might happen. In Olson (1965) argument, individuals made his/her own benefit-cost expectations in order to make choice whether or not to participate in collective action. People are assumed to participate because of selective incentives, that is, if the private benefits go beyond the private cost. In this case, usually private cost exceeds private benefits, and free-rider problem likely to occur. Weible use Collective Interest Model to elucidate factor that affect stakeholders' participation in collaborative institution of Marine Protected Areas and tries to overcome this free-rider problem by setting up additional collective interest variables which represent ally efficacy and instrument efficacy

Similarly, the idea of social capital initiated to overcome the dilemmas of collective action (Lochner, Kawachi, \& Kennedy, 1999). The dilemmas of collective action firstly introduced by Mancur Olson(1965)in his book The Logic of Collective Action, and later the use of economic tools in analyzing individual behavior within group is rising eventually. Collective action can be defined as the combining of resources to achieve a common, communitywide goal (Tilly, 1973). A more specific definition of collective action is provided by Meinzen - Dick, DiGregorio, and McCarthy (2004), who propose that for an activity to qualify as a collective action, it must meet four criteria. The activity must involve a group of people, the people in the group must have a shared interest, the group must work to extra that shared interest, and the members of the group must do so voluntarily (i.e., not as paid staff of an organization).

Collective action can exist in many varied forms. Some examples include participation community development projects (Ryan, Agnitsch, Zhao \& Mullick, 2005), participation in participatory budgeting processes (Su, 2016; Weber, Crum, \& Salinas, 2015), and engagement with neighborhoods watch groups (Pattavina, Byrne, \& Garcia, 2006; Smith; van Eijk, Steen, \& Verschuere, 2017). Definition of collective action differentiating from civic commitment and civic participation, for example, an individual can be an active citizen by voting, attending community or local government meetings, or writing an opted article. Although these activities may meet some of the criteria for collective action as defined above, they do not address them all; therefore, they may be worthwhile forms of civic engagement and participation, but they are not collective actions. 
Theories of collective action explain setting on a group of individuals, a common interest among them, and potential conflict between the common interest and each individual's interest (Ostrom \& Ahn, 2003). Olson (1965) dispute that without force, an individual with self-interest motives is always better off by choosing not to cooperate with others, and more likely to free-ride to enjoy collective benefit at cost of others. This is possible since collective goods have non-excludable property on enjoying it. alike argument expressed by Hardin (1968) that in the context of exploitation for collective resource, individual for all time end to have narrow-minded view that he/she would exploit the resource at the maximum until the resource exhaust, which is known by 'the tragedy of the commons'. In the context of public goods provision, this can be described by free-riders problem. But, Runge (1984) developed assumption that if there is some kind of contract that ties the agents, cooperation will occur. Furthermore, Ostrom (1990) explained that if agents have infinite perspective in looking the ongoing cooperation, then they tend to cooperate. Representatives will be aware of making mistakes since the other agent will have opportunity to punish or make revenge. That is why an arm's length (Hayami \& Godo, 2005) in community context is important as Olson (1965) argue that small group is an exclusion for collective action to be possible since in this situation, iterative interaction happened and the possibility of monitoring as well as punishing free-riding behavior may make participation more likely.

Fehr \& Fischbacher(2002) illustrate how to put social preference in the context of collective action instead of analyzing collective action in individual context. It is assumed that individual can be grouped into several types: selfish and conditional cooperators. Conditional cooperators are people who are willing to contribute more to a public good the more others contribute. Conditional cooperation can be considered as a motivation in its own or be a consequence of some fairness preferences like 'altruism', 'warm-glow', 'inequity aversion', or 'reciprocity'. In this literature review study it was shown that a third of the subjects could be classified as free riders, where as 50 percent as conditional cooperators (Fischbacher et. al., 2001). Gould (1993) has developed a clear mathematical model about interdependency on individual decision to contribute in a collective action difficulty.

In this scenario, individual responds to the contributions of others because of effectiveness concerns and norms of fairness. This assumption likely will have dissimilar result from Olson's formulation (1965) which individual as rational egoist will have the optimal solution not to contribute; or become free rider. Some studies have tried to relate collective action problem with social capital concept. Some keyword for this relation is reciprocity, trust, altruism, conditional cooperation, networks, institutions, social norms and rules.

Ahn and Ostrom (2002) have defined such relation by the second generation of collective action. Second generation of collective action is the development of earlier theory on collective action which framed by the Prisoner's Dilemma game, where in the first-generation theories of collective action is an image of atomized, selfish, and fully rational individuals. The change has been made on the assumption on individual that it was confirmed in reality and empirical study, mostly in field and laboratory experiment, there is a significant portion of individual that act non-selfish behavior (Ostrom \& Ahn, 2003). Weible (2008) also tried to explain how cooperation might happen. In Olson (1965) argument, individuals made his/her own benefit-cost expectations in order to make option whether or not to participate in collective action. People are assumed to participate because of selective incentives, that is, if the private benefits exceed the private cost. In this case, usually private cost exceeds private benefits, and free-rider problem likely to occur. Weible use Collective Interest.

\subsection{The role of social capital on collective action in natural resource management}

Based on empirical literature review of reputable journals and articles, the following summary of discussions are worth drawn:

Carbone (2019) in the study of bonding social capital and collective action revealed that individuals with higher bonding social capital will have a higher probability of having engaged in collective action. Whereas, individuals who have engaged in collective action have a greater probability of having a more negative neighborhood perception as compared with individuals who have not engaged in collective action.

According to Bisung and Elliott 2014), study indicated that apart from financial challenges, the lack of social capital is a barrier to collective action for community based water and sanitation initiatives .Similarly, As Von Below et al(2020), found that investment in building social capital may have some contextual benefits for collective action to address common environmental challenges. The findings also informed that policy interventions in investing social capita in water and sanitation delivery in low and middle income countries, environmental health promotion and community development are crucial.

Pretty and Ward (2001) indicated that most natural resource management groups with effective social capital are small, ranging from 20 to 30 members for effective collective action. Whereas Wuthnow (1994) suggested that the ideal group size for maximum trust building is no $>15-20$ people for a community achieving common goals . Similarly, Wagner, Kreuter and Kaise (2007) examined Collective Action and Social Capital of Wildlife Management Associations, revealed that small (>30 members) rather than large ( $>100)$ are crucial for wildlife management associations may be more effective for building social capital as a capacity for collective action . Group size is an important aspect of social capital building because as membership increases it becomes more 
difficult to develop trust and reciprocity relationships among members (Wuthnow 1994).

Suharti , Darusman (2016) in study of social capital to strengthen collective action in environmental protection showed that social variables namely, trust and civic engagement are highly and significantly affecting collective action in community development programs .As well, individual characteristics like gender, education and age are found to greatly affecting collective action in community development endeavors. In consistency with the study,Qurniat, Febryano and Zulfiani (2017) found that the aforementioned variables are significantly and positively affecting collective action in community development programs. On the contrary to this study, it was found that household income and size are negatively affecting collective action.

Rahman and Hickey (2015) examined the role of social capital in community collective action for sustainable wetland fisheries in Bangladesh. The study used multiple regression model to estimate the influence eight independent human capital variables on collective action. As a result of which limited number memberships and heterogeneity index have a considerable positive impact collective action. Importantly, the study indicated that minimum number of members required to establish a community fisheries organization is 20 , suggesting that the organization tries to limit the number of members to the lowest number possible in order to optimize individual payoff.

In the contrast, meeting attendance, index of participation had a considerably negative influence on collective action. The index of participation had a negative influence on collective action because most of the decisions in the fisheries organization were taken by the community leaders. The study also revealed that collective action requires a significant contribution of social capital that comes in three forms: bonding, linking and bridging. Bonding social capital is an individual household asset which creates trust and reciprocity among the community members and fuels collective action (Dale and Newman 2008). In confirmation to this study, Dale and Sparkes (2007) found that bonding social capital is necessary for the collective action of both community members who form a fisheries organization and those that don't. Consequences also indicated that community leaders bridged the gap between community members and external agents through linking and bridging social capital, playing a central role in collective decision making.

Uphoff (1993) examined the role of grassroots organizations and NGOs in rural development: opportunities with diminishing states and expanding markets. The study found that formally developed organizations are generally more active to attain their organizational objectives and are characterized by a higher degree of rule imposition. However, as of Ostrom(1990), some organizations may also develop informally and can contribute significantly to regulating natural resource use.

Numerous studies have also identified that natural resource management requires augmented community cooperation ,trust and institutionalization when bonding, bridging and linking social capital prevail simultaneously in a community (Dale and Sparkes 2007; Dale and Newman 2008). In these situations, higher levels of bonding social capital facilitates trust, reciprocity and unselfish behavior among community members which are necessary ingredients for cooperation ,operational rule setting, enforcement, transparency and accountability (Ostrom 2009). Bridging and linking social capital work to assist with information generation and dispersal within a community, and are essential for collective action to achieve common goals. Inconstancy with the above findings, Kim (2018) in the study effects of social capital on collective action in community development, found that bridging and linking qualities of social networks produced a strong influence on collective action more than any other variable. However, the effect of community-level social trust was small and did not explain the extent to which individuallevel social networks exerted influence on collective action.

According to Pretty (2003), highlighted that social capital is central to community-based development circumstance because it facilitates the establishment of user groups through trust, reciprocal behavior and connectedness with external agents (e.g., credit access, information providers, political groups etc.) As a result, individuals with higher degree of social capital are more likely to participate in collective actions because they can access more information, develop linkages and engage in decision making processes (Agrawal and Ostrom 2001; Pretty and Ward 2001)

Krishna $(2002,2011)$ examined that bridging and linking social capital is maintained by community leaders who keep communication with outside institutions In these situations, the role of local leaders is crucial for the collective action of the community because they hold symbolic power in collective decision making and largely determine how informal institutions operate(Ballet et al. 2007). Local leaders generally perform these activities by organizing and mobilizing collective actions, and also by voluntarily establishing linkages with external agents through their own efforts and personal networks (e.g., governmental officials, political groups and credit sources) on behalf of potential user groups (Bodin and Crona 2009).

Kim (2018) assessed the effects of social capital on collective action for community development. Used generalized linear model and concluded that social networks have a critical impact on collective action especially for the underprivileged that lack resource mobilization opportunities. Specifically, the bridging and linking qualities of social networks produced a strong influence on collective action more than any other variable. However, the effect of community-level social trust was small and did not explain the extent to which individual-level social 
networks exerted influence on collective action.

Ido ( 2019) examined the effect of social capital on collective action in community forest management in Cambodi using ordered logistic regression. The study indicated that social capital variables namely, social networks and cooperative norms had positive effects on collective actions. The findings of the study aligns with the social capital literature, such as Putnam's theory, which has argued that horizontal networks promote collective action (Putnam et al. 1993). Cooperative norms also had a positive effect on collective action in community forest management, indicating that communities members shared a high level of cooperative norms were more likely to participate. This is because CF members participate in patrols based on cooperative norms to solve the forest degradation problem faced by the community.

Qurniati , Febryano, Zulfiani (2017.) examined how trust influence social capital to support collective action in agro forestry development .The study found that trust is an important factor for strengthening social capital. The study also argued that trust in forest community is achieved through collective action in small scale agro forestry. It was challenging process regards the low on social capital in communities. The study also revealed that trust between farmer group members remains high. However, trust as a source of social capital was not supported collective action since farmer group institution is weak. Therefore, to support agro forestry development, social capital should be increased through the development of good networks (bridging) to reach collective goal i.e. community welfare and sustainable forest management.

Hwang and Stewart (2017) in the study of social capital and collective action in rural truism indicated that the qualities of one's social networks are relevant to the tendency to participate in tourism development. The closer one's relationship to a community leader of tourism development, the more likely they are to be part of communitybased efforts for tourism development. The result also revealed that, compared to individualized personal ties among residents, already existing social organizations were critical to enhance collective action of residents. An implication for increased participation in tourism development is for community leaders to reach out and learn from residents who are isolated or less central within community leadership networks.

\section{Methodology}

Data analysis was employed in order to examine the objectives under study. Purposely, theoretical and inferential information was reviewing from a number of independent studies of the same subject, in order to determine the common trends. The roles of social capital (SC) on collective actions (CA) in nature resource management were analyzed by reviewing different relevant literatures.

\subsection{Source of data}

Theoretical and empirical literature review on relevant to the role of human capital in collective action on natural resource management; it includes among others, in the areas of :

- $\quad$ Environmental protection

- $\quad$ Forest management

- Truism management activities ,

- Common pooled resource management

- Water, soil and fishery management

- $\quad$ Climate change management

- $\quad$ Wild life management

- $\quad$ Agro- forestry development

\section{Conclusions and recommendations}

Based on investigating a series of theoretical and empirical evidences on the role of social capital in collective action, mainly in natural resource management areas, the following conclusions and recommendations are worth drawn:

Examined literatures generally indicated that natural resources need protection from destructive actions of people to achieve sustainable development. Yet communities have shown in the past and increasingly today that they can collaborate for long-term resource management. Social capital variables like heterogeneity index, bridging and linking social capital, civic engagement, cooperative norms, limited numbers of participants and formalized groups are found to be very significant and positively affecting collective action for community's achieving sustainable natural resource development. Particularly, the variables are playing a fundamental role in reducing transaction cost of exchange; reduce cost of enforcing rules and information asymmetry ;and improve local authority performance by pooling them in the networks .Likewise, the study found that in an homogeneous communities trust is a critical element for collective action even in un limited number of participants. Specifically, most studies confirmed that bridging and linking social networks produced a strong influence on collective action more than any other variable. However, the effect of community-level social trust was small and did not explain 
far more than individual-level (leaders) social networks exerted influence on collective action. Furthermore, bridging and linking social capital are very significant for mobilizing collective actions, and voluntarily establishing linkages with external agents through their own efforts (e.g., governmental officials, political groups and credit sources) on behalf of potential user groups.

Likewise, most literatures have also found that in a homogeneous community, bonding social capital considered as a success factor for facilitating trust, reciprocity and unselfish behavior among community members. Consecutively, which are necessary ingredients for cooperation, operational rule setting, enforcement, transparency and accountability for achieving common goals of community collective action? Top above, most literatures also identified that effective management of collective action, mobilization of bridging and linking social capital are equally important as they do not only help mobilize external resources but, at times, also promote bonding social capital

This study is also aimed to review literatures to investigate whether there is positive relation between social capital and collective environmental action. Most study used model estimation of social capital variables in collective action revealed that the higher the social capital level, the more likely individual is willing to contribute in collective action to protect the natural resource. Results also found that individuals with higher degree of social capital are more likely to participate in collective actions because they can access more information, develop linkages and engage in decision making processes. Similarly, based on the findings, most literature also showed that in formalized groups, social capital is high, and people have the confidence to invest in collective activities in achieving their common natural resource goals.

Similarly, study indicated that aside from financial challenges, lack of social capital is a barrier to collective action for community based natural resource management. Nearly all literatures also suggested that investment in building social capital have diverse benefits for collective action to address common environmental challenges. Findings alike inform that investing in social capital variables are very crucial for policy interventions and practice in natural resource management particularly in low and middle income countries. In consistency with the findings, group size is also indicated as a significant aspect of social capital building because as membership increases it becomes more difficult to develop trust and reciprocity relationships among members.

As per the findings of the study, it is recommended that policy makers may take due consideration that investment in building social capital have multi-dimensional benefits for collective action to address natural resource management challenges

\section{Reference}

Agrawal A, Ostrom E (2001) Collective action, property rights, and decentralization in resource use in India and $\mathrm{N}$

Ahn, T.K. and Ostrom, E., 2002, August. Social capital and the second-generation theories of collective action: An analytical approach to the forms of social capital. In annual meeting of the American Political Science Association (Vol. 29).

Auer, A., Von Below, J., Nahuelhual, L., Mastrangelo, M., Gonzalez, A., Gluch, M., Vallejos, M., Staiano, L., Laterra, P. and Paruelo, J., 2020. The role of social capital and collective actions in natural capital conservation and management. Environmental Science \& Policy, 107, pp.168-178.

Bourdieu, D. (1996). Participation, Social Capital, and Intersectoral Problem Solving: African and Asian Cases. World Development, 24 (9), 1467-1479.

Cahyono B. 2014. The role of social capital in improving the community welfare of tobacco farmers in Wonosobo regency. Ekobis 15 (1): 1- 16.

Carbone, J.T., 2019. Bonding social capital and collective action: Associations with residents' perceptions of their neighbourhoods. Journal of Community \& Applied Social Psychology, 29(6), pp.504-519.

Cardenas, J.-C., \& Ostrom, E. (2004). What do People Bring Into the Game? Experiments in the Field about Cooperation in the Commons. Agricultural Systems , 82, 307-326

Claibourn, M.P. and Martin, P.S., 2000. Trusting and joining? An empirical test of the reciprocal nature of social capital. Political Behavior, 22(4), Miller, A.S. and Mitamura, T., 2003. Are surveys on trust trustworthy?. Social Psychology Quarterly, pp.62-70.p.267-291.

Coleman, J. S. (1988). Social Capital and the Creation of Human Capital. The American Journal of Sociology , 94 (Supplement), S95-S120.

Coleman, J.S., 1988. Social capital in the creation of human capital. American journal of sociology, 94, pp.S95S120.

Dale A, Newman L (2008) Social capital: a necessary and sufficient condition for sustainable community development? Community Development Journal 45(1):5-21

Dale A, Sparkes J (2007) Protecting ecosystems: network structure and social capital mobilization. Community Development Journal 43(2): 143-156

Dasgupta, P., 2000. Economic progress and the idea of social capital. Social capital: A multifaceted perspective, 
pp.325-424.

DiPasquale, D. and Glaeser, E.L., 1999. Incentives and social capital: Are homeowners better citizens?. Journal of urban Economics, 45(2), pp.354

Douangngeune, B., Hayami, Y. and Godo, Y., 2005. Education and natural resources in economic development: Thailand compared with Japan and Korea. Journal of Asian Economics, 16(2), pp.179-204.

D'Silva, E. and Pai, S., 2003. Social capital and collective action: Development outcomes in forest protection and watershed development. Economic and political weekly, pp.1404-1415

Fehr, E. and Fischbacher, U., 2005. Human altruism-proximate patterns and evolutionary origins. Analyse \& Kritik, 27(1), pp.6-47.

Fischbacher, U., Gächter, S. and Fehr, E., 2001. Are people conditionally cooperative? Evidence from a public goods experiment. Economics letters, 71(3), pp.397-404

Fisher R. 2013. 'A gentleman's handshake': the role of social capital and trust in transforming information into usable knowledge. J Rural Stud 31: 13-22.

Guillen LA, Wallin I, Brukas V. 2015. Social capital in small-scale forestry: a local case study in Southern Sweden. For Pol Econ 53: 21-28

Hwang, D. and Stewart, W.P., 2017. Social capital and collective action in rural tourism. Journal of travel research, 56(1), pp.81-93

Ido, A.,2019. The effect of social capital on collective action in community forest management in Cambodia. International Journal of the Commons, 13(1)..

Innah HI, Suharjito D, Dharmawan AH, Darusman D. 2013. Collective action typologies and reforestation in indigenous community of Biak, Papua. Jurnal Manajemen Hutan Tropika 19 (1): 11-22.

Iswandono E, Zuhud EAM, Hikmat A, Kosmaryandi N. 2015. Integrating local culture into forest conservation: a case study of the Manggarai tribe in Ruteng Mountains, Indonesia. Jurnal Managemen Hutan Tropika 21 (2): 55-64.

Kim, H.Y., 2018. Effects of social capital on collective action for community development. Social Behavior and Personality: an international journal, 46(6), pp.1011-1028.

Knack, S. and Keefer, P., 1997. Does social capital have an economic payoff? A cross-country investigation. The Quarterly journal of economics, 112(4), pp.1251-1288.

Krishna A (2011) Gaining access to public services and the democratic state in India: institutions in the middle.

Leonardi, R., Nanetti, R.Y. and Putnam, R.D., 2001. Making democracy work: Civic traditions in modern Italy. Princeton, NJ: Princeton university press.

Lochner, K., Kawachi, I. and Kennedy, B.P., 1999. Social capital: a guide to its measurement. Health \& place, 5(4), pp. $259-270$

Meinzen-Dick, R., DiGregorio, M. and McCarthy, N., 2004. Methods for studying collective action in rural development

Nooteboom B. 2006. Social capital, institutions and trust. Discussion Paper 35: 1-22.

Ostrom E (1994) Constituting social capital and collective action. Journal of Theoretical Politics 6(4):527-562

Ostrom E (2009) Building trust to solve commons dilemmas: taking small steps to test an evolving theory of collective action. In: Levin SA (ed) Goods and global goods games. Springer, Berlin, pp 207-228evelopment? Community Development Journal 45(1):21

Ostrom, E. and Ahn, T.K., 2003. A social science perspective on social capital: social capital and collective action. Revista Mexicana De Sociologia, 65(1), pp.155-233.

Ostrom, E., 1990. The evolution of institutions for collective action. Edición en español: Fondo de Cultura Económica, México.

Pattavina, A., Byrne, J.M. and Garcia, L., 2006. An examination of citizen involvement in crime prevention in high-risk versus low-to moderate-risk neighborhoods. Crime \& Delinquency, 52(2), pp.203-231

Pretty J, Ward H (2001) Social capital and the environment. World Development 29(2):209-227 epal. Politics and Society 29(4):485-514

Pretty, J. and Ward, H., 2001. Social capital and the environment. World development, 29(2), pp.209-227.

Putnam RD, Leonardi WR, Nonetti RY. 1993. Making Democracy Work Civic Traditions in Modern Italy. Princeton University Press, New Jersey.

Putnam, R., 1993. The prosperous community: Social capital and public life. The american prospect, 13(Spring), Vol. 4. Available online: http://www. prospect. org/print/vol/13 (accessed 7 April 2003).

Putnam, R., Leonardi, R. and Nanetti, R., 1993. Making democracy work Princeton. NJ: Princeton University Piess.

Qurniati, r., Febryano, I.g. and Zulfiani, d., 2017. How trust influence social capital to support collective action in agroforestry development?. Biodiversitas Journal of Biological Diversity, 18(3), pp.1201-1206.

Qurniati, r., Febryano, I.g. and Zulfiani, d., 2017. how trust influence social capital to support collective action in agroforestry development?. Biodiversitas Journal of Biological Diversity, 18(3), pp.1201-1206 
Rahman, H.T., Hickey, G.M. and Sarker, S.K., 2015. Examining the role of social capital in community collective action for sustainable wetland fisheries in Bangladesh. Wetlands, 35(3), pp.487-499.

Roslinda E, Ekyastuti W, Kartikawati SM. 2017. Social capital of community forest management on Nusapati Village, Mempawah District, West Kalimantan, Indonesia. Biodiversitas 18 (2): 558-564.

Rothstein, B. and Stolle, D., 2001, September. Social capital and street-level bureaucracy: An institutional theory of generalized trust. In ESF Conference Social Capital: Interdisciplinary Perspectives, Exeter, UK September15-20.

Ryan, V.D., Agnitsch, K.A., Zhao, L. and Mullick, R., 2005. Making sense of voluntary participation: A theoretical synthesis. Rural Sociology, 70(3), pp.287-313.

StBodin O, Crona BI (2009) The role of social networks in natural resource governance: what relational patterns make a difference? Global Environmental Change 19:366-374udies in Comparative International Development

Stolle, Dietlind. "'Getting to trust': An analysis of the importance of institutions, families, personal experiences and group membership." In Social capital and participation in everyday life, pp. 118-133. Routledge, 2003

Suharti, S., Darusman, D., Nugroho, B. and Sundawati, L., 2016. Strengthening social capital for propelling collective action in mangrove management. Wetlands Ecology and Management, 24(6), pp.683-695.

Szreter, S. and Woolcock, M., 2004. Health by association? Social capital, social theory, and the political economy of public health. International journal of epidemiology, 33(4), pp.650-667.

Tzanakis, M., 2013. Social capital in Bourdieu's, Coleman's and Putnam's theory: empirical evidence and emergent measurement issues. Educate , 13(2), pp.2-23

Uphoff N (1993) Grassroots organizations and NGOs in rural development: opportunities with diminishing states and expanding markets. World Development 21(4):607-622

Uphoff, N., 2000. Understanding social capital: learning from the analysis and experience of participation. Social capital: A multifaceted perspective, 6(2), pp.215-249

Wagner, M.W., Kreuter, U.P., Kaiser, R.A. and Wilkins, R.N., 2007. Collective action and social capital of wildlife management associations. The Journal of wildlife management, 71(5), pp.1729-1738.

Weber, R., Crum, T. and Salinas, E., 2015. The civics of community development: participatory budgeting in Chicago. Community Development, 46(3), pp.261-278.

Weible, C.M., 2008. Expert - based information and policy subsystems: a review and synthesis. Policy Studies Journal, 36(4), pp.615-635.

Woolcock, M., 1998. Social capital and economic development: Toward a theoretical synthesis and policy framework. Theory and society, 27(2), pp.151-208.
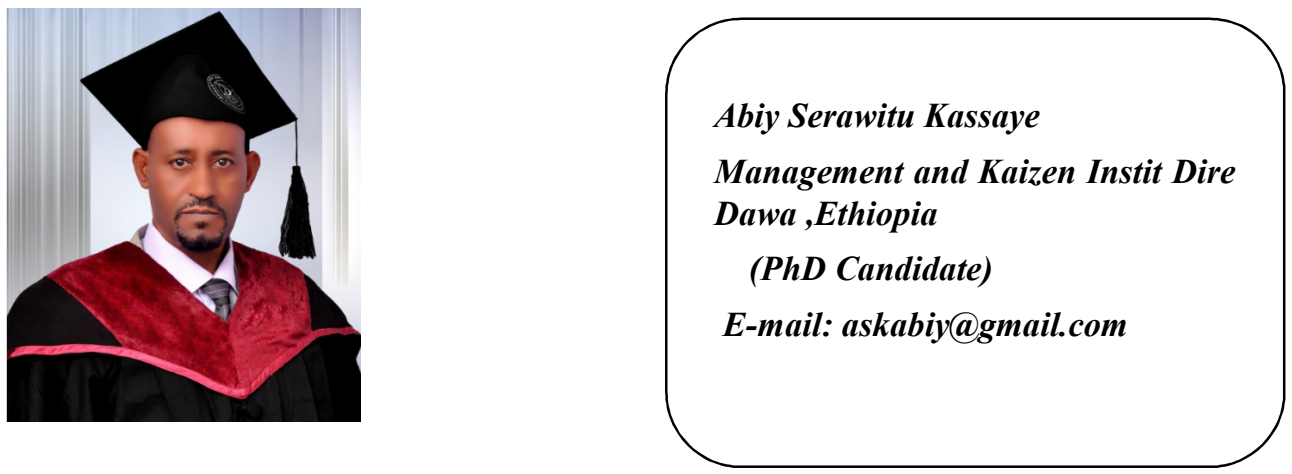